Check for updates

Cite this: RSC Adv., 2018, 8, 10457

Received 12th December 2017

Accepted 8th February 2018

DOI: $10.1039 / c 7 r a 13268 a$

rsc.li/rsc-advances

\section{Optimization of simultaneous production of volatile fatty acids and bio-hydrogen from food waste using response surface methodology $\dagger$}

\begin{abstract}
Nuo Liu, (D) Jianguo Jiang, (DD *ab Feng Yan, (D) a Yiwen Xu, ${ }^{a}$ Meng Yang, ${ }^{a}$ Yuchen Gao, ${ }^{a}$ Aikelaimu Aihemaiti ${ }^{a}$ and Quan Zou ${ }^{a}$

Anaerobic digestion of food waste (FW) is commonly considered an effective and green technology to convert solid waste into valuable feedstock including volatile fatty acids (VFAs) and hydrogen. Response surface methodology (RSM) was selected to analyze the production of VFAs and hydrogen from food waste in a batch process. The effect of the three variables i.e. total solid content (TS), $\mathrm{pH}$, and reaction time under each variable at three levels on VFAs and hydrogen production was assessed. The optimum conditions determined via $\mathrm{RSM}$ were $\mathrm{pH}=7.0, \mathrm{TS}=100 \mathrm{~g} \mathrm{~L}^{-1}$, and reaction time $=3 \mathrm{~d}$. The maximum VFA and hydrogen production was $26.17 \mathrm{~g} \mathrm{~L}^{-1}$ and $46.03 \mathrm{~mL} \mathrm{~g}^{-1}$ volatile solids added, respectively. The ratio of observed hydrogen $\left(H_{0}\right)$ to predicted hydrogen $\left(H_{p}\right)$ was $x<1.0$ because of inhibition of hydrogen production by VFA accumulation. The subsequent microbial community analysis result was also consistent with the abovementioned results. The evolution of Bacteroidetes, which facilitate VFA production, has been enriched by about 16.1-times at $\mathrm{pH} 7.0$ followed by 10.2 -times at $\mathrm{pH} 6.0$ as compared to that in the uncontrolled $\mathrm{pH}$ batch.
\end{abstract}

\section{Introduction}

In recent years, more than 60 million-ton food waste (FW) is generated per year in China due to population growth and economic development. ${ }^{1} \mathrm{FW}$ has received public attention due to its quantity, odor, and potential for pathogenic microorganism contamination. ${ }^{2} \mathrm{FW}$ contains a high moisture and salt/ oil content; hence, conventional treatment such as incineration or sanitary landfill may cause environmental and health risks. ${ }^{3}$ Anaerobic digestion is considered as an effective alternative method for treating FW because of its ability to produce highvalue products (e.g. volatile fatty acids [VFAs] and hydrogen) in an environmentally friendly way. ${ }^{4}$ Use of $\mathrm{FW}$ as a feedstock for anaerobic fermentation to form VFAs and hydrogen enables the production of high-value products and reduces waste material; this makes anaerobic fermentation a novel and promising approach. ${ }^{5}$

Commonly, hydrolysis and acidogenesis occur during anaerobic digestion processes to produce VFAs. At first, complex compounds in food waste are broken into small compounds by enzymes, and then, the resulting small organic

${ }^{a}$ School of Environment, Tsinghua University, Beijing 100084, China. E-mail: jianguoj@tsinghua.edu.cn

${ }^{b}$ Key Laboratory for Solid Waste Management and Environment Safety, Ministry of Education of China, Beijing 100084, China

$\dagger$ Electronic supplementary information (ESI) available. See DOI: $10.1039 / \mathrm{c} 7 \mathrm{ra} 13268 \mathrm{a}$ compounds are converted into VFAs by the action of microbes. Moreover, hydrogen is generated as a by-product. ${ }^{6}$

VFAs and hydrogen are two high-value products of anaerobic fermentation. The produced VFAs can be used as an efficient carbon source in wastewater treatment, ${ }^{7,8}$ whereas hydrogen is considered an effective alternative to the current fossil fuels. In addition, both VFAs and hydrogen may be used as precursors of chemical products. ${ }^{9}$

In previous studies, efforts have been made to maximize the VFA and hydrogen production through exploring different kinds of wastes including FW, garden waste, cattle waste, sludge, and mixtures. In addition, optimization of parameters, such as $\mathrm{pH}$, temperature, and total solid content (TS), during anaerobic digestion has been considered. Typically, to optimize the parameters of an anaerobic process, the traditional approach about just one variable a time on VFA production is commonly accepted. ${ }^{10}$ However, the abovementioned method is not able to evaluate the interaction between multiple variables.

In this study, we focused on the potential of FW as a raw material to produce VFAs and hydrogen; the production was optimized using response surface methodology (RSM). The parameters, including $\mathrm{pH}$, temperature, and total solid content (TS), especially their interactions, were optimized during anaerobic digestion. A Box-Behnken design for three variables, each at three levels, was used to model the process. The TS, volatile solid (VS), soluble chemical oxygen demand (SCOD), and the microbial community analysis were also assessed. 


\section{Materials and methods}

\subsection{Substrate and inoculum}

FW produced at a campus cafeteria was complex and difficult to homogenize; therefore, we analyzed its composition and prepared a mixture that represented several traditional food ingredients to simulate real FW. All food ingredients were purchased from the campus market. The FW comprised a mixture of rice (35\% by weight), cabbage ( $45 \%$ by weight), pork ( $16 \%$ by weight), and tofu ( $4 \%$ by weight). The mixture was processed in a food grinder with tap water and stored at $4{ }^{\circ} \mathrm{C}$. Its characteristics are presented in Table 1 .

Anaerobically digested sludge has been obtained from the Gaobeidian Wastewater Treatment Plant (Beijing, China), which has a sewage treatment capacity of $1.0 \times 10^{6}$ $\mathrm{m}^{3}$ per day. The sewage treatment plant uses an anaerobicanoxic-oxic processing system to treat municipal wastewater. The sludge was obtained from the anaerobic digester after gravity thickening and anaerobic digestion were completed. The characteristics of the inoculum sludge are listed in Table 1.

\subsection{Batch experiments}

The TS content of each reactor was adjusted to 5 , 8 , or $10 \%$ with deionized water, and the substrate was composed of about $85 \%$ stimulated FW and 15\% anaerobic sludge (wet weight). In all batches, $300 \mathrm{~mL}$ of a FW slurry was treated with $50 \mathrm{~g}$ sludge as measured by the VS content. All reactors were stirred at $120 \mathrm{rpm}$ using a magnetic stirrer throughout the experiment. Anaerobic fermentation was conducted for 5 days. The amount of biogas produced was sampled using $0-10 \mathrm{~mL}$ syringes.

The batch reactors were operated at the $\mathrm{pH}$ values 4.0, 5.0, 6.0 , and 7.0 as well as at uncontrolled $\mathrm{pH}$. Wherever necessary, the $\mathrm{pH}$ was adjusted periodically using $1.0 \mathrm{M} \mathrm{HCl}$ or $\mathrm{NaOH}$ to maintain the desired values. Therefore, $\mathrm{pH} 7.0$ meant that the initial $\mathrm{pH}$ was adjusted to 7.0; the $\mathrm{pH}$ was then allowed to decrease at the start of fermentation using $1.0 \mathrm{M} \mathrm{HCl}$ or $\mathrm{NaOH}$ to maintain the $\mathrm{pH}$ at 6.8 to facilitate hydrogen production by bacteria. ${ }^{\mathbf{1 1 1 2}}$ Moreover, other $\mathrm{pH}$ conditions were readjusted, and the $\mathrm{pH}$ was maintained at the designed values of about $\mathrm{pH}$ 6.0, pH 5.0, and pH 4.0.

Table 1 Basic characteristics of the food waste and inoculum ${ }^{a}$

\begin{tabular}{|c|c|c|}
\hline Items & Food waste & Inoculum \\
\hline TS $(\%)^{b}$ & $10.98 \pm 2.04$ & $4.5 \pm 0.05$ \\
\hline $\operatorname{VS}(\%)^{c}$ & $10.95 \pm 2.21$ & $2.2 \pm 0.04$ \\
\hline VS/TS (\%) & $97.7 \pm 1.11$ & $48.54 \pm 0.36$ \\
\hline VFAs $\left(\mathrm{mg} \mathrm{L}^{-1}\right)^{d}$ & $829.53 \pm 103.16$ & $568.4 \pm 116.05$ \\
\hline $\mathrm{pH}$ & $4.59 \pm 0.17$ & $6.34 \pm 0.09$ \\
\hline C (\% TS) & $49.97 \pm 0.15$ & $24.48 \pm 0.05$ \\
\hline $\mathrm{H}(\% \mathrm{TS})$ & $6.79 \pm 0.01$ & $3.45 \pm 0.01$ \\
\hline $\mathrm{N}(\% \mathrm{TS})$ & $3.72 \pm 0.06$ & $2.88 \pm 0.02$ \\
\hline $\mathrm{C} / \mathrm{N}$ & $13.43 \pm 0.18$ & $8.49 \pm 0.04$ \\
\hline
\end{tabular}

${ }^{a}$ Mean \pm standard deviation of three samples. ${ }^{b} \mathrm{TS}$, total solids. ${ }^{c} \mathrm{VS}$, volatile solids. ${ }^{d}$ VFAs, volatile fatty acids.

\subsection{Analytical methods}

The $\mathrm{pH}$ was measured using a pH meter (DRION STAR A214; Thermo Electron, West Palm Beach, FL, USA). Elemental compositions were determined using the CE-440 elemental analyzer (Exeter Analytical Inc., North Chelmsford, MA, USA). TS and VS were analyzed in accordance with standard methods. ${ }^{13}$ The SCOD was measured using the Hach Method 8000 and a DR 5000 spectrometer (Hach, Loveland, CO, USA). VFAs (acetate, propionate, butyrate, iso-butyrate, valerate, and isovalerate) and ethanol were measured using a gas chromatograph (GC-2010 Plus; Shimadzu, Tokyo, Japan). The VFA samples were centrifuged at $15000 \mathrm{rpm}$ for $15 \mathrm{~min}$, filtered through a $0.45 \mu \mathrm{m}$ membrane, and the $\mathrm{pH}$ was adjusted to $<2.0$ using $25 \% \mathrm{H}_{3} \mathrm{PO}_{4}$ before injection into the gas chromatograph, which was equipped with a capillary column (Stabilwax-DA, 30 $\mathrm{m} \times 0.32 \mathrm{~mm} \times 0.25 \mu \mathrm{m}$, Restek Corp., Bellefonte, PA, USA) and a flame ionization detector. The injector and detector temperatures were 220 and $250{ }^{\circ} \mathrm{C}$, respectively. The column temperature was increased from 60 to $150{ }^{\circ} \mathrm{C}$ at the rate of $7{ }^{\circ} \mathrm{C} \mathrm{min}{ }^{-1}$, held at $150{ }^{\circ} \mathrm{C}$ for $5 \mathrm{~min}$, increased to $230{ }^{\circ} \mathrm{C}$ at the rate of $20{ }^{\circ} \mathrm{C} \mathrm{min}^{-1}$, and finally held at $230{ }^{\circ} \mathrm{C}$ for $10 \mathrm{~min}$.

The biogas composition (mainly $\mathrm{H}_{2}$ and $\mathrm{CO}_{2}$ ) was measured by the gas chromatograph, which was equipped with a thermal conductivity detector and a View the MathML source (inside diameter) stainless steel column packed with Porapak N (80100 mesh). The injector, detector, and column temperatures were maintained at 50,100 , and $50{ }^{\circ} \mathrm{C}$, respectively. Argon was used as the carrier gas at the flow rate of $30 \mathrm{~mL} \mathrm{~min}^{-1}$. A $0.5 \mathrm{~mL}$ sample was injected each time.

The V4 region of the 16S rRNA gene was amplified using barcoded primers (forward: GTGCCAGCMGCCGCGGTAA, reverse: GGACTACHVGGGTWTCTAAT) and a polymerase chain reaction (PCR) approach. The PCRs were run on the ABI GeneAmp ${ }^{\circledR} 9700$ system (Applied Biosystems, Foster City, CA, USA) using the following program: $5 \mathrm{~min}$ of denaturation at $95{ }^{\circ} \mathrm{C}$, followed by 30 cycles of $30 \mathrm{~s}$ at $95{ }^{\circ} \mathrm{C}$ (denaturation),

Table 2 Analysis of variance (ANOVA) of the experiment ${ }^{a}$

\begin{tabular}{lccccc}
\hline Source & $\begin{array}{l}\text { Sum of } \\
\text { squares }\end{array}$ & df & $\begin{array}{l}\text { Mean } \\
\text { square }\end{array}$ & $F$ value & $\begin{array}{l}P \text {-value } \\
\text { prob- } F\end{array}$ \\
\hline Model & 406.299 & 9 & 45.14434 & 10.36476 & 0.0028 \\
$A$-TS & 226.2601 & 1 & 226.2601 & 51.94742 & 0.0002 \\
$B$-pH & 45.23966 & 1 & 45.23966 & 10.38665 & 0.0146 \\
$C$-reaction time & 71.52363 & 1 & 71.52363 & 16.42123 & 0.0049 \\
$\mathrm{AB}$ & 15.38113 & 1 & 15.38113 & 3.53138 & 0.1023 \\
$\mathrm{AC}$ & 9.646328 & 1 & 9.646328 & 2.214716 & 0.1803 \\
$\mathrm{BC}$ & 0.192368 & 1 & 0.192368 & 0.044166 & 0.8395 \\
$A^{2}$ & 0.374251 & 1 & 0.374251 & 0.085925 & 0.7779 \\
$B^{2}$ & 10.65046 & 1 & 10.65046 & 2.445255 & 0.1619 \\
$C^{2}$ & 43.59838 & 1 & 43.59838 & 10.00982 & 0.0158 \\
Residual & 30.48892 & 7 & 4.355559 & & \\
Lack of fit & 30.48892 & 5 & 6.097783 & & \\
Pure error & 0 & 2 & 0 & & \\
Cor total & 436.788 & 16 & & & \\
${ }^{a} R$-squared 0.9302, adj $R$-squared 0.8405, pred $R$-squared 0.0738, adeq \\
precision 12.602.
\end{tabular}




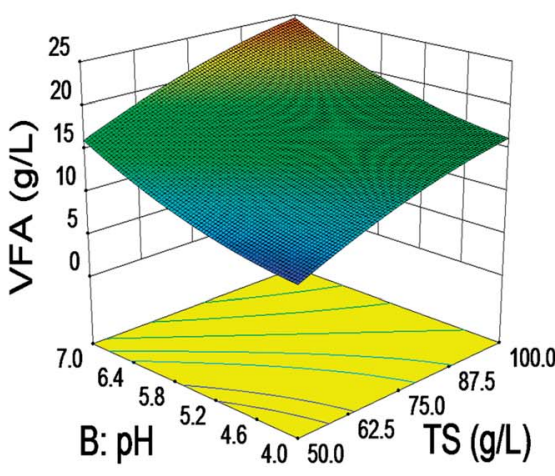

(a)

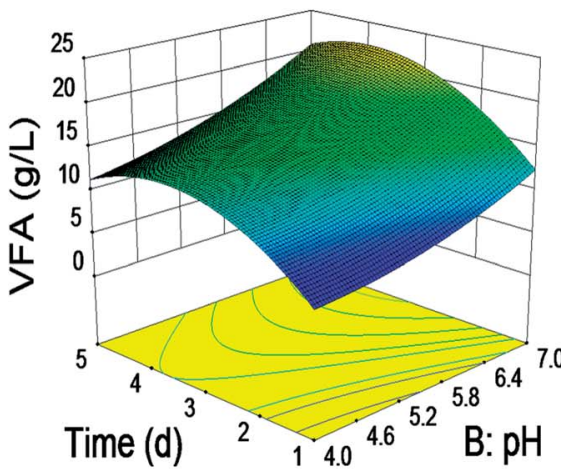

(c)

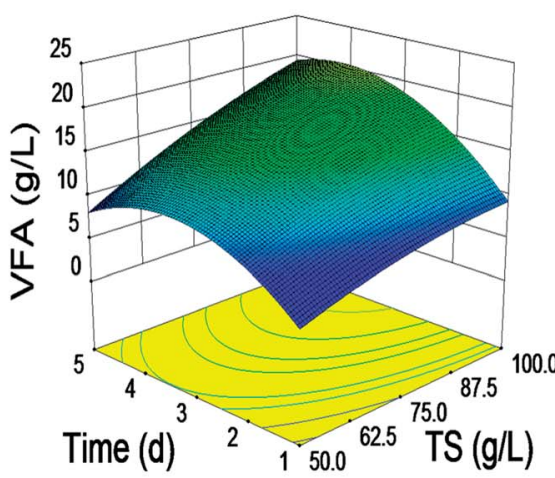

(e)

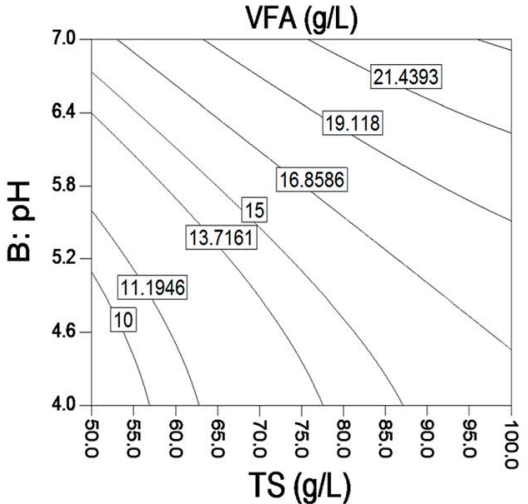

(b)

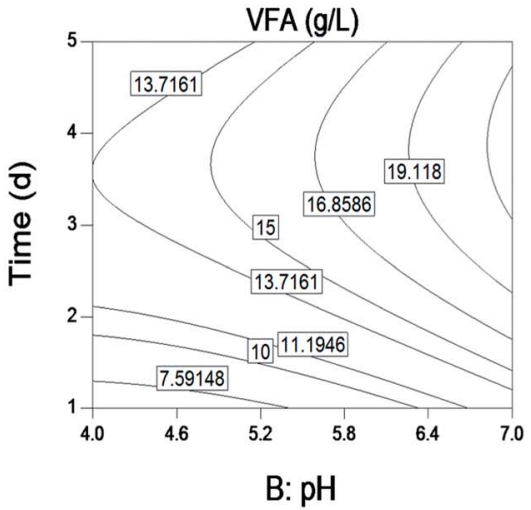

(d)

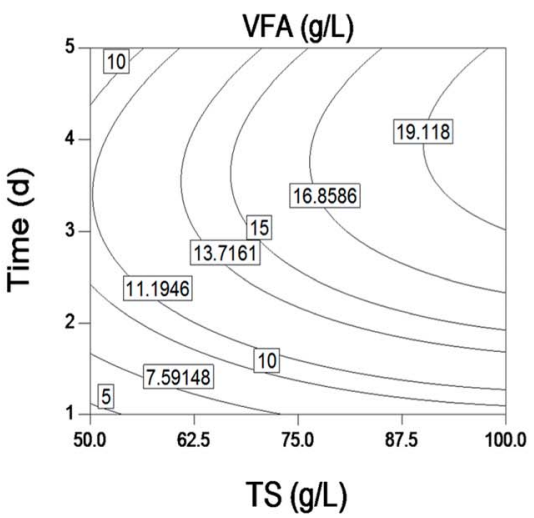

(f)

Fig. 1 3D response surface and contour plots: effect of (a) and (b) TS ( $\mathrm{g} \mathrm{L}^{-1}$ ) and pH; (c) and (d) $\mathrm{pH}$ and time (d); (e) and (f) pH TS (g L ${ }^{-1}$ ); and time (d).

$30 \mathrm{~s}$ of annealing at $58{ }^{\circ} \mathrm{C}, 25 \mathrm{~s}$ at $72{ }^{\circ} \mathrm{C}$ (elongation), and a final extension at $72{ }^{\circ} \mathrm{C}$ for $7 \mathrm{~min}$. The products obtained from different samples were mixed at equal ratios for sequencing using the Illumina HISeq 2500 platform (Illumina Inc., San Diego, CA, USA). The Ribosomal Database Project (RDP) Classifier (ver. 2.2) was used for taxonomic assignments against the RDP 16S rRNA training set 9 with the confidence scores $\geq 0.8$. The weighted and unweighted UniFrac distance matrices were calculated as beta-diversity metrics and visualized with principal coordinates analysis in QIIME. ${ }^{14}$
A Box-Behnken design for three variables, each at three levels, was used for the model tested by RSM. Thus, 17 group experiments were designed. The software Design Expert 8.0 was used to organize the process. All the details are shown in Table $\mathrm{S} 2 . \dagger$

\section{Results and discussion}

\subsection{Model fitting analysis}

The model $F$-value of 10.36 implies that the model is significant (Table 2). There is only a $0.28 \%$ chance that this large model $F$-Value 
Table 3 Comparison of VFA production in the relevant literature

\begin{tabular}{|c|c|c|c|c|}
\hline Substrate & Inoculum & Operational conditions & VFAs & References \\
\hline Food waste & Dewatered sludge & $\mathrm{pH} 9.0,35^{\circ} \mathrm{C}$ & $25.93 \mathrm{~g} \mathrm{COD} / \mathrm{L}$ & 23 \\
\hline Kitchen waste & Waste-activated sludge & $\mathrm{pH} 8.0,37^{\circ} \mathrm{C}$ & $692.4 \mathrm{mg} \mathrm{COD} / \mathrm{g} \mathrm{VS}$ & 24 \\
\hline Waste activated sludge & - & pH $11.0,25^{\circ} \mathrm{C}$ & $219.7 \mathrm{mg} \mathrm{COD} / \mathrm{g}$ VS & 25 \\
\hline Food waste & Sludge & $37^{\circ} \mathrm{C}$, microwave & $23.02 \mathrm{~g} \mathrm{~L}^{-1}$ & 26 \\
\hline Food waste & Excess sludge & $40^{\circ} \mathrm{C}$ & $867.42 \mathrm{mg} \mathrm{COD} / \mathrm{g} \mathrm{VS}$ & 27 \\
\hline
\end{tabular}

can occur due to noise. Values of prob $>F$ less than 0.0500 indicate that the model terms are significant. In this case, $A, B, C$, and $C^{2}$ are significant model terms. Values greater than 0.1000 indicate that the model terms are not significant. Adeq precision measures the signal-to-noise ratio. A ratio greater than 4 is desirable. The ratio of this research is 12.602, which indicates an adequate signal. Overall, the VFA production equation fitted in terms of various factors was observed as follows:

$$
\begin{aligned}
\mathrm{VFAs}= & 12.61+5.10 A+2.30 B+3.07 C+1.92 \mathrm{AB}+1.61 \mathrm{AC} \\
& +0.22 \mathrm{BC}+0.32 A^{2}+1.82 B^{2}-3.33 C^{2}
\end{aligned}
$$

\subsection{Response surface analysis of various factors}

The optimum level of each of the various factors (TS, $\mathrm{pH}$, reaction time) for VFA production and the interaction effects of these variables were analyzed using 3D response surfaces and $2 \mathrm{D}$ contours for two variables with the other one remaining at its optimum level (Fig. 1).

The effects of pH and TS are shown in Fig. 1(a) and (b). The RSM indicated that VFA production gradually increased with the increasing TS content and $\mathrm{pH}$. This finding is consistent with our previous study. ${ }^{4}$ It was clear that the higher TS content released more nutrition into the batch system, benefiting the microbial community, which then increased VFA production. ${ }^{15}$ There is a threshold TS content that is dependent on the rheology and mass transfer of the system. ${ }^{16}$ VFA production was different at different TS contents and $\mathrm{pH}$ values. The optimal $\mathrm{pH}$ for VFA production was 7.0 regardless of the TS. The maximum VFA production of $26.17 \mathrm{~g} \mathrm{~L}^{-1}$ was achieved with $100 \mathrm{~g} \mathrm{~L}^{-1}$ TS and $\mathrm{pH}$ 7.0.

Fig. 1(c) and (d) show the interaction of $\mathrm{pH}$ and reaction time. At the lowest $\mathrm{pH}$ and reaction time, VFA production was extremely low. The VFA production increased gradually to reach a maximum as the $\mathrm{pH}$ and reaction time increased, and then, it decreased. The optimal reaction time and $\mathrm{pH}$ for VFA production were $3 \mathrm{~d}$ and 7.0, respectively.

Fig. 1(e) and (f) reflect the interaction of TS and reaction time. As with the $\mathrm{pH}$ and reaction time, at the lowest TS content and reaction time, VFA production was extremely low. The VFA response increased gradually to reach a maximum as the TS content and reaction time increased, and then, it decreased. The reaction time is another important parameter in anaerobic digestion for VFA and hydrogen production and should be taken into consideration. The results obtained by Kim et al. showed that hydraulic reaction time contributed more to VFA production rather than the temperature of the reactor. ${ }^{17}$ Obviously, a longer reaction time provides enough time for microbes to react with the substrate; this subsequently benefits VFA production. However, there is an optimal reaction time beyond which there is no further increase in VFA production. ${ }^{\mathbf{1 8}}$

Overall, the maximum VFA concentrations were obtained at $\mathrm{pH}$ 7.0, TS $100 \mathrm{~g} \mathrm{~L}^{-1}$, and reaction time $3 \mathrm{~d}$. This finding is consistent with our previous study. ${ }^{4}$ Other studies have reported that the maximum VFA concentration was observed at $\mathrm{pH}$ 6.0.
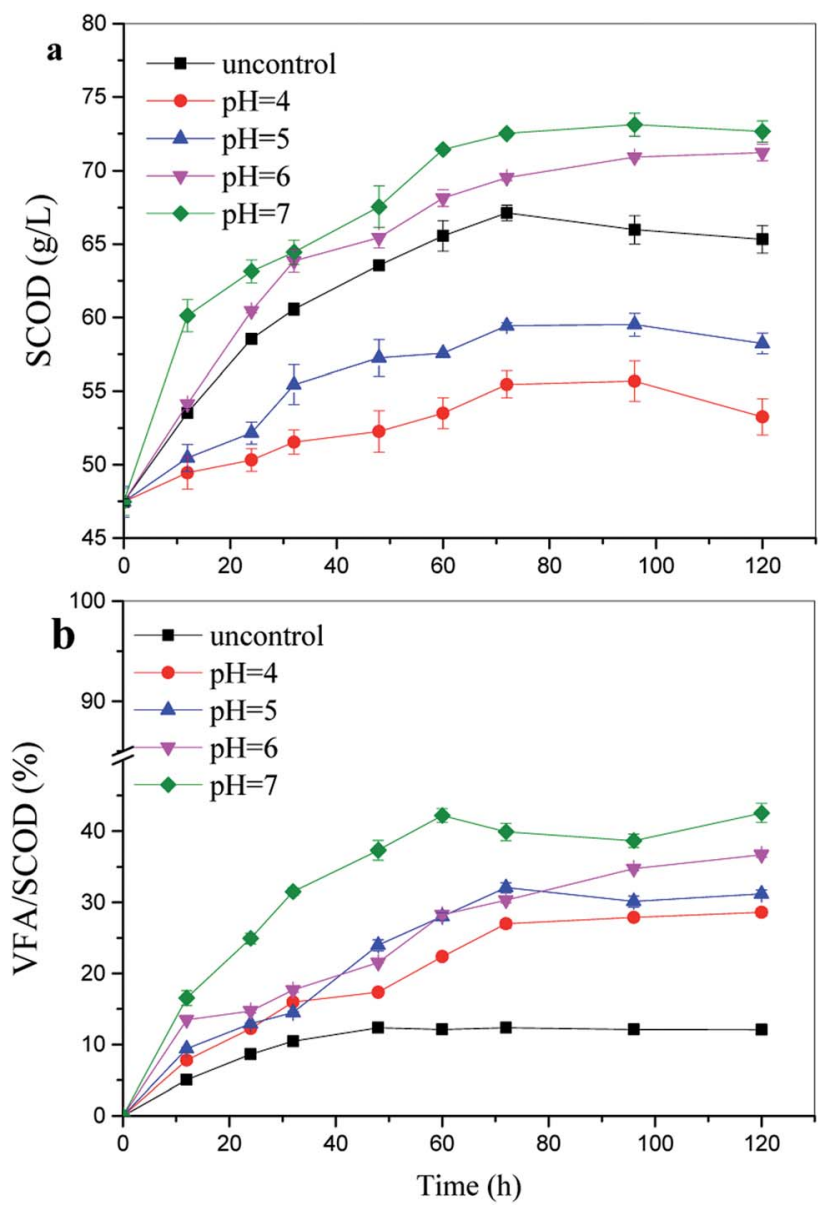

Fig. 2 Soluble chemical oxygen demand (SCOD) concentrations and the percentage of volatile fatty acid (VFA)/SCOD at various $\mathrm{pH}$ values and $100 \mathrm{~g} \mathrm{TS} / \mathrm{L}$. 
This difference in the optimal $\mathrm{pH}$ value may be due to the characteristics of the inoculum. Wang et al. stated that the optimal $\mathrm{pH}$ value of kitchen waste for VFA production by anaerobic digestion was equal to $7,{ }^{19}$ whereas a comparative study reported by Dahiya et al. showed that higher VFA production was obtained under alkaline conditions rather than under acidic or neutral conditions. ${ }^{6}$ Lee et al. have pointed out that the optimal $\mathrm{pH}$ value for VFA production ranges from 5.25 to 11 , and it depends on the characteristics of the substrate composition and inoculum (Table 3). ${ }^{\mathbf{1 6}}$ Herein, the VFA production increased with the $\mathrm{pH}$ value regardless of TS (Fig. 1); this meant that $\mathrm{pH}$ values at 7.0 were more favorable for VFA production than other $\mathrm{pH}$ values tested in this study. The maximum VFA production was achieved at $\mathrm{pH}$ 7.0, followed by at the $\mathrm{pH}$ values of 6.0 and 5.0. This was similar to the results reported by Dahiya et al. (2015), who discovered that a high $\mathrm{pH}$ reactor system enhanced the hydrolysis of carbohydrates and proteins by causing ionization and facilitating fermentation. In this study, VFA concentrations at $\mathrm{pH} 4.0$ and with uncontrolled $\mathrm{pH}$ reactor increased more slowly during fermentation than under other conditions; this was mainly caused by the inhibition of acidogenesis at $\mathrm{pH}<4.0 .^{20}$

To evaluate the potential of the FW raw material for VFA production more convincingly, VFA production per VS content added ( $\mathrm{g} \mathrm{g}^{-1} \quad \mathrm{VS}_{\text {added }}$ ) was also determined (Table $\mathrm{S} 1 \dagger$ ). According to the result, a level of $0.416 \mathrm{~g} \mathrm{~g}^{-1} \mathrm{VS}_{\text {added }}$ was obtained at the TS of $50 \mathrm{~g} \mathrm{~L}^{-1}$, followed by $0.315 \mathrm{~g} \mathrm{~g}^{-1} \mathrm{VS}_{\text {added }}$ at $80 \mathrm{~g} \mathrm{~L}^{-1}$ and $0.305 \mathrm{~g} \mathrm{~g}^{-1} \mathrm{VS}_{\text {added }}$ at $100 \mathrm{~g} \mathrm{~L}^{-1}$. The results indicated that the VFA production increased with the increasing TS content up to a point; however, a higher TS content inhibited
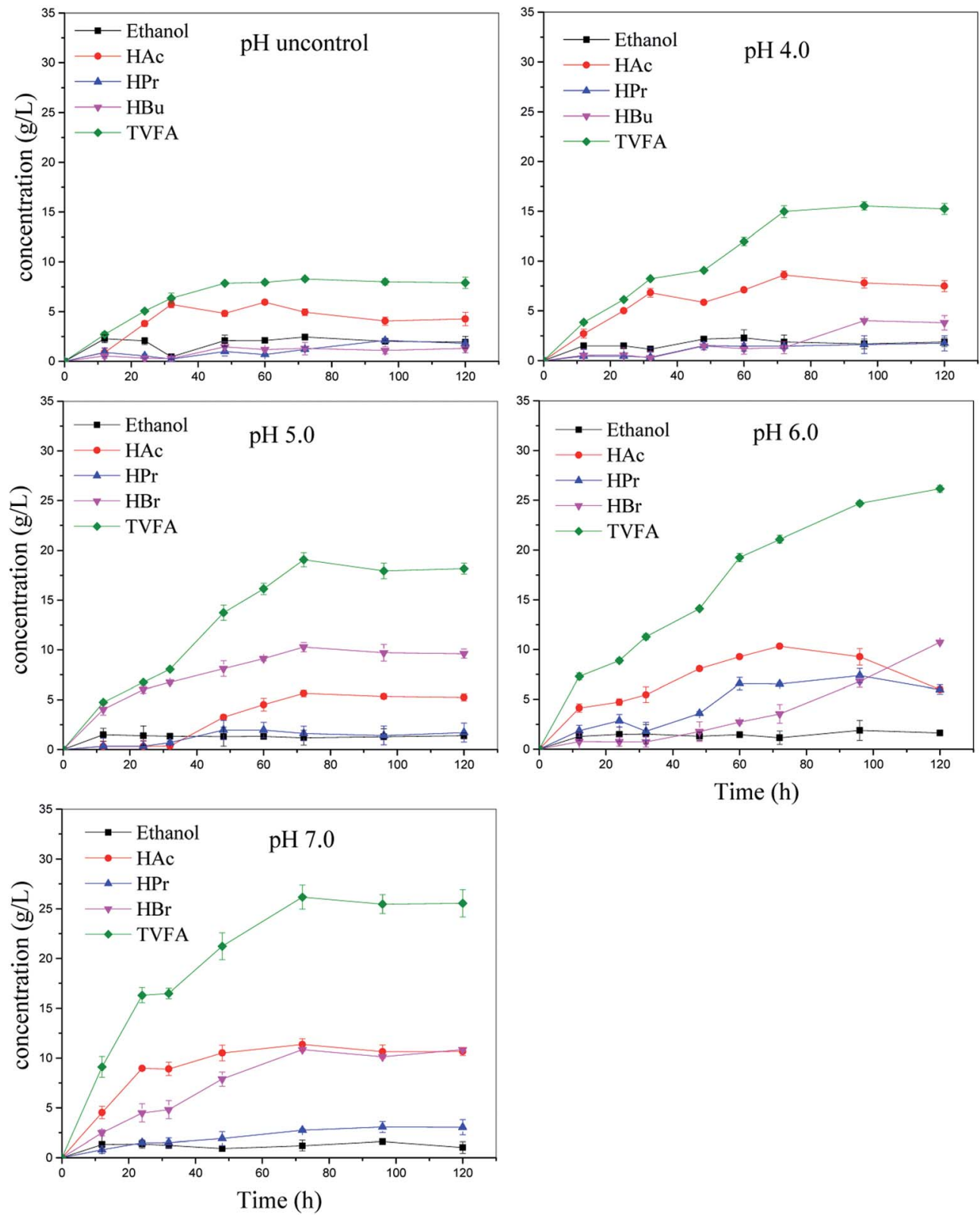

Time (h)

Fig. 3 VFAs and ethanol concentration at various $\mathrm{pH}$ values and $100 \mathrm{~g} \mathrm{TS} / \mathrm{L}$. 
further degradation; this subsequently led to a lower conversion efficiency of VFA production ( $\mathrm{g} \mathrm{g}^{-1} \mathrm{VS}_{\text {added }}$ ). This conclusion was consistent with the research of Khan et al. who stated that the hydrolysis reduced if the organic loading rate increased beyond a certain value. ${ }^{21}$

The microbial community analysis (Fig. S1a†) also proved the abovementioned results. The result shows that Firmicutes, Proteobacteria, Bacteroidetes, and Actinobacteria are the predominant phyla regardless of $\mathrm{pH}$. Specially, Bacteroidetes include anaerobic rod-shaped bacteria that are widely distributed in the environment, and their fermentation products always include acetic acid, hydrogen, and ethanol. ${ }^{22}$ This phylum was enriched by about $1.2,10.2$, and 16.1 times at the $\mathrm{pH}$ values of 5.0, 6.0, and 7.0, respectively, as compared to the uncontrolled $\mathrm{pH}$ batch (Fig. $\mathrm{S} 1 \mathrm{~b} \dagger$ ).

\subsection{Conversion percentage of VFA/SCOD and the VFA composition}

In addition, the VFA/SCOD ratio is commonly used to estimate the degree of soluble material converted into VFAs. ${ }^{28}$ Furthermore, a higher VFA/SCOD ratio of about $42.4 \%$ was achieved at $\mathrm{pH} 7.0$; this indicated that the $\mathrm{pH} 7.0$ enabled the anaerobic microorganisms to convert soluble compounds into VFAs better than at the other $\mathrm{pH}$ values reported in this study (Fig. 2).

Then, the composition of the VFAs produced is another important parameter representing the degree of hydrolysis and fermentation. ${ }^{29}$ The main VFAs produced herein were acetic, butyric, and propionic acids (Fig. 3). Acetic and butyric acids were the most prevalent VFAs in all the reactors, accounting for $>70 \%$ of the total VFA production. These results indicated that butyric-type

Table 4 The Gompertz model constants for different $\mathrm{pH}$ values ${ }^{a}$

\begin{tabular}{lrrrr}
\hline $\mathrm{pH}$ & \multicolumn{1}{l}{$P(\mathrm{~mL})$} & \multicolumn{1}{c}{$R_{\mathrm{m}}\left(\mathrm{mL} \mathrm{h}^{-1}\right)$} & \multicolumn{1}{c}{$\lambda(\mathrm{h})$} & \multicolumn{1}{c}{$R^{2}$} \\
\hline Uncontrolled & $7.39 \pm 0.02$ & $0.63 \pm 0.02$ & $-2.1 \pm 0.27$ & 0.96 \\
4.0 & $188.43 \pm 0.98$ & $4.07 \pm 0.08$ & $8.27 \pm 0.49$ & 0.96 \\
5.0 & $502.94 \pm 6.44$ & $15.19 \pm 1.02$ & $16.46 \pm 1.17$ & 0.94 \\
6.0 & $1106.4 \pm 8.9$ & $47.93 \pm 1.84$ & $55.9 \pm 0.45$ & 0.99 \\
7.0 & $1381.53 \pm 11.3$ & $38.68 \pm 0.93$ & $32.57 \pm 0.66$ & 0.98
\end{tabular}

${ }^{a}$ Mean \pm standard error. fermentation was achieved. ${ }^{28}$ This phenomenon indicated that the $\mathrm{pH}$ value controlled the total VFA generation rather than the effect of the ratios of acetate, butyrate, and propionate. ${ }^{30}$ The ethanol concentration remains stable during the anaerobic digestion.

\subsection{Evaluation of hydrogen production and its interaction with VFAs}

$\mathrm{CH}_{4}$ was not detected in this 5 day fermentation process. ${ }^{31} \mathrm{~A}$ modified Gompertz model ${ }^{32}$ was applied to analyze the kinetics of hydrogen production during fermentation.

$$
H=P \exp \left\{-\exp \left[R_{\mathrm{m}} e(\lambda-t) / P+1\right]\right\}
$$

where $H$ is the cumulative hydrogen production $(\mathrm{mL}), \lambda$ is the lag time (h), $P$ is the hydrogen production potential $(\mathrm{mL}), R_{\mathrm{m}}$ is the maximum hydrogen production rate $\left(\mathrm{mL} \mathrm{h}^{-1}\right), e$ is 2.718281828, and $t$ represents the time (h). The Origin 9.0 software was used for the curve fitting and calculation (Table 4).

All correlation coefficients ( $R$-square) of nonlinear analysis by the modified Gompertz model were over 0.93, suggesting that the modified Gompertz model was able to describe the cumulative hydrogen production well. Obviously, the maximum cumulative hydrogen yield was obtained at $\mathrm{pH}$ 7.0. This result is consistent with the results of other researchers. $^{2}$

Furthermore, the predicted molar $\mathrm{H}_{2}$ production was calculated by the equation $M_{\mathrm{H}}=V_{\mathrm{H}} / R T$, where $R=0.08$ (L atm) (mol $\mathrm{K})^{-1}$ and $T=308 \mathrm{~K}$. The predicted $\mathrm{H}_{2}$ production was calculated by the equations given below:

$$
\begin{gathered}
\mathrm{C}_{6} \mathrm{H}_{12} \mathrm{O}_{6}+2 \mathrm{H}_{2} \mathrm{O} \rightarrow \text { 2ethanol }+2 \mathrm{H}_{2}+2 \mathrm{CO}_{2} \\
\mathrm{C}_{6} \mathrm{H}_{12} \mathrm{O}_{6}+2 \mathrm{H}_{2} \mathrm{O} \rightarrow 2 \mathrm{HAc}+4 \mathrm{H}_{2}+2 \mathrm{CO}_{2} \\
\mathrm{C}_{6} \mathrm{H}_{12} \mathrm{O}_{6} \rightarrow \mathrm{HBu}+2 \mathrm{H}_{2}+2 \mathrm{CO}_{2}
\end{gathered}
$$

The distributions of VFA production and predicted $\mathrm{H}_{2}$ production are shown in Table 5 . Acetate and butyrate were the main soluble products regardless of the $\mathrm{pH}$ condition. According to eqn (3)-(5), the theoretical $\mathrm{H}_{2}$ production can be predicted from the ethanol and volatile acid concentration. ${ }^{33}$ The results range from 233.7 to $651.7 \mathrm{mmol}$. The highest

Table 5 Soluble products and predicted $\mathrm{H}_{2}$ yield under different initial $\mathrm{pH}$ conditions

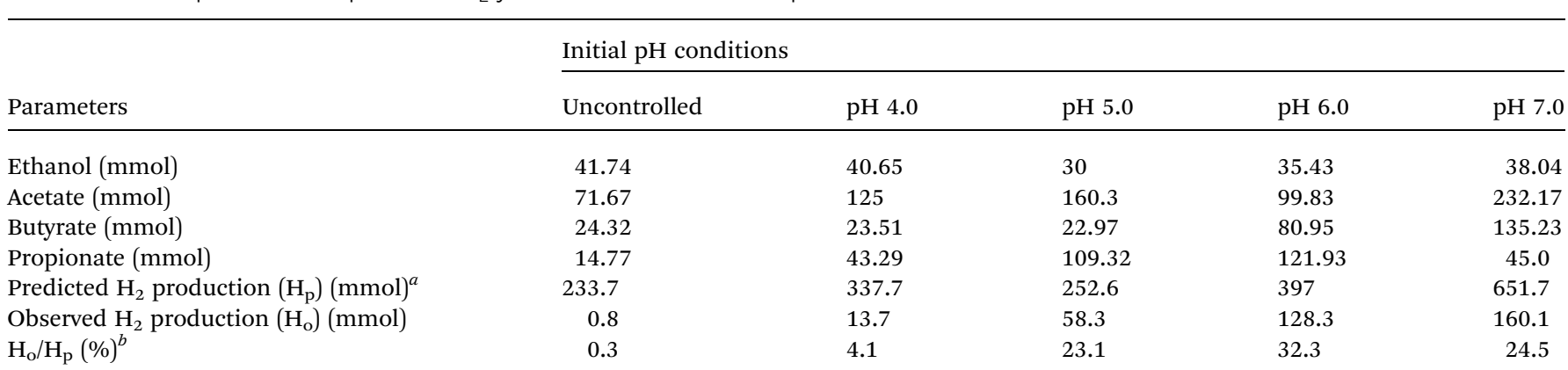

${ }^{a}$ Based on eqn (2)-(4), assuming that production of $1 \mathrm{~mol}$ of ethanol accompany 1 mol of $\mathrm{H}_{2}$ production, and 1 mol of acetate and butyrate production accompany $2 \mathrm{~mol}$ of $\mathrm{H}_{2}$ production. ${ }^{b}$ The ratio of observed $\mathrm{H}_{2}$ production and predicted $\mathrm{H}_{2}$ production. 

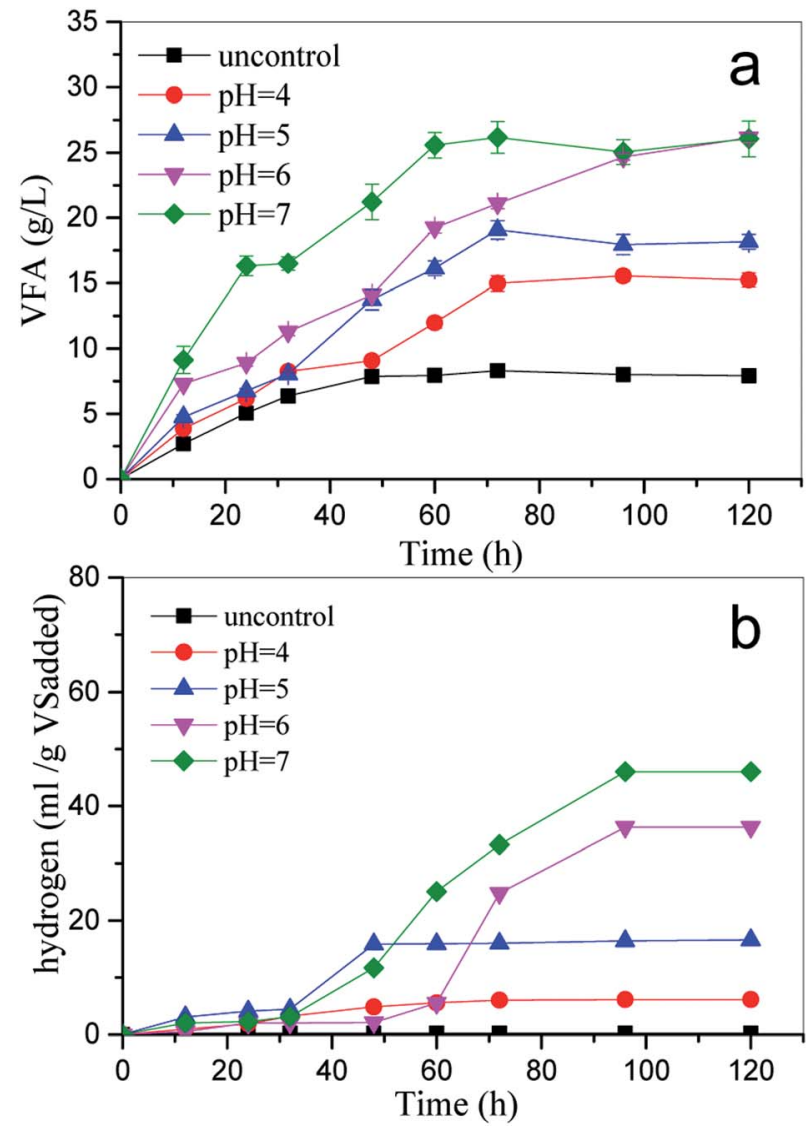

Fig. 4 VFA concentration (a) and hydrogen production (b) under optimal conditions.

predicted $\mathrm{H}_{2}$ production was $651.7 \mathrm{mmol}$ at $\mathrm{pH}$ 7.0, followed by $397 \mathrm{mmol}$ at $\mathrm{pH}$ 6.0. It was speculated that there was no $\mathrm{H}_{2}$ loss through conversion to $\mathrm{CH}_{4}$ because no $\mathrm{CH}_{4}$ was detected. Thus, the ratio of observed hydrogen $\left(\mathrm{H}_{\mathrm{o}}\right)$ to predicted hydrogen $\left(\mathrm{H}_{\mathrm{p}}\right)$, i.e. $\mathrm{H}_{\mathrm{o}} / \mathrm{H}_{\mathrm{p}}$, theoretically should be close to 1 in the reaction system. However, it was difficult to achieve according to the result (Table 4). The gap was mainly caused by the VFA accumulation, and other reasons, such as the adsorption to the liquid phase, also influenced the $\mathrm{H}_{\mathrm{o}} / \mathrm{H}_{\mathrm{p}}$ value. $^{33}$

Moreover, in this study, the accumulation of VFA production altered and rendered the micro-environment unfavorable for the growth of hydrogen-producing microbes, mainly responsible for the gap (Fig. 4); Tapia-Venegas et al. $^{34}$ achieved a higher $\mathrm{H}_{\mathrm{o}} / \mathrm{H}_{\mathrm{p}}$ value of about $61-80 \%$ accompanied by a lower VFA production (lower $5 \mathrm{mg} \mathrm{L}^{-1}$ ).

\section{Conclusions}

RSM was proved to be a useful method to predict VFA production under variable factors. The optimum conditions for the reactors studied in this work analysis via $\mathrm{RSM}$ were $\mathrm{pH}=7.0$, TS $=100 \mathrm{~g} \mathrm{~L}^{-1}$, and reaction time $=3 \mathrm{~d}$. While the ratio of $\mathrm{H}_{\mathrm{o}} / \mathrm{H}_{\mathrm{p}}$ for hydrogen production under the optimal condition was around 0.323 , lower than the theoretical value of 1.0 ; this was mainly caused by the effects of VFA accumulation on the microbes in the reactor. Our findings were also consistent with those of the microbial community analysis. The maximum evolution of Bacteroidetes, which facilitate VFA production, was enriched by 16.1 times at $\mathrm{pH} 7.0$ as compared to that in the uncontrolled $\mathrm{pH}$ batch.

\section{Conflicts of interest}

There are no conflicts of interest to declare.

\section{Acknowledgements}

This work was supported financially by the Major Science and Technology Program for Water Pollution Control and Treatment (2017ZX07202005).

\section{References}

1 Y. Jin, Y. Li and J. Li, J. Environ. Manage., 2016, 180, 291-300.

2 N. H. M. Yasin, T. Mumtaz, M. A. Hassan and N. A. Abd Rahman, J. Environ. Manage., 2013, 130, 375-385.

3 L. Zhang and D. Jahng, Waste Manage., 2012, 32, 1509-1515. 4 J. Jiang, Y. Zhang, K. Li, Q. Wang, C. Gong and M. Li, Bioresour. Technol., 2013, 143, 525-530.

5 I. K. Kapdan and F. Kargi, Enzyme Microb. Technol., 2006, 38, 569-582.

6 S. Dahiya, O. Sarkar, Y. V. Swamy and S. V. Mohan, Bioresour. Technol., 2015, 182, 103-113.

7 H. Zhang, J. Jiang, M. Li, F. Yan, C. Gong and Q. Wang, J. Environ. Manage., 2016, 166, 407-413.

8 A. Singh, S. Sevda, I. Abu Reesh, K. Vanbroekhoven, D. Rathore and D. Pant, Energies, 2015, 8, 12357.

9 R. R. Singhania, A. K. Patel, G. Christophe, P. Fontanille and C. Larroche, Bioresour. Technol., 2013, 145, 166-174.

10 C. P. C. Bong, L. Y. Lim, C. T. Lee, J. J. Klemeš, C. S. Ho and W. S. Ho, J. Cleaner Prod., 2018, 172, 1545-1558.

11 Y. M. Wong, T. Y. Wu and J. C. Juan, Renewable Sustainable Energy Rev., 2014, 34, 471-482.

12 K. Wang, J. Yin, D. Shen and N. Li, Bioresour. Technol., 2014, 161, 395-401.

13 APHA, AWWA and WEF, APHA, Standard methods for the examination of water and wastewater, 2005, Washington, DC, USA.

14 Q. Wang, G. M. Garrity, J. M. Tiedje and J. R. Cole, Appl. Environ. Microbiol., 2007, 73, 5261-5267.

15 J. Yu, J. Biotechnol., 2001, 86, 105-112.

16 W. S. Lee, A. S. M. Chua, H. K. Yeoh and G. C. Ngoh, Chem. Eng. J., 2014, 235, 83-99.

17 W. Kim, S. G. Shin, J. Lim and S. Hwang, Bioprocess Biosyst. Eng., 2013, 36, 791-798.

18 S.-J. Lim, B. J. Kim, C.-M. Jeong, J.-d.-r. Choi, Y. H. Ahn and H. N. Chang, Bioresour. Technol., 2008, 99, 7866-7874.

19 Y. Wang, B. Zang, G. Li and Y. Liu, Waste Manage., 2016, 53, 62-67.

20 N. H. M. Yasin, T. Mumtaz and M. A. Hassan, J. Environ. Manage., 2013, 130, 375-385. 
21 M. A. Khan, H. H. Ngo, W. S. Guo, Y. Liu, L. D. Nghiem, F. I. Hai, L. J. Deng, J. Wang and Y. Wu, Bioresour. Technol., 2016, 219, 738-748.

22 L. Niu, L. Song and X. Dong, Int. J. Syst. Evol. Microbiol., 2008, 58, 12-16.

23 H. Chen, H. Meng, Z. Nie and M. Zhang, Bioresour. Technol., 2013, 128, 533-538.

24 Y. Chen, J. Luo, Y. Yan and L. Feng, Appl. Energy, 2013, 102, 1197-1204.

25 H. Yu, Z. Wang, Q. Wang, Z. Wu and J. Ma, Chem. Eng. J., 2013, 231, 206-213.

26 Y. Zhang, X. C. Wang, Z. Cheng, Y. Li and J. Tang, Chemosphere, 2016, 144, 689-696.

27 Q.-L. Wu, W.-Q. Guo, H.-S. Zheng, H.-C. Luo, X.-C. Feng, R.-L. Yin and N.-Q. Ren, Bioresour. Technol., 2016, 216, 653-660.
28 W. Guo, Q. Wu, S. Yang, H. Luo, S. Peng and N. Ren, RSC Adv., 2014, 4, 53321-53326.

29 K. Wang, J. Yin, D. Shen and N. Li, Bioresour. Technol., 2014, 161, 395-401.

30 J. B. Van Lier, K. C. Grolle, C. T. Frijters, A. J. Stams and G. Lettinga, Appl. Environ. Microbiol., 1993, 59, 1003-1011.

31 K. Li, R. Liu and C. Sun, Renewable Sustainable Energy Rev., 2016, 54, 857-865.

32 D.-H. Kim, S.-H. Kim, K.-W. Jung, M.-S. Kim and H.-S. Shin, Bioresour. Technol., 2011, 102, 8646-8652.

33 W. Han, M. Ye, A. J. Zhu, H. T. Zhao and Y. F. Li, Bioresour. Technol., 2015, 191, 24-29.

34 E. Tapia-Venegas, J. E. Ramirez, A. Donoso-Bravo, L. Jorquera, J.-P. Steyer and G. Ruiz-Filippi, Int. J. Hydrogen Energy, 2013, 38, 2185-2190. 